\title{
SEISMIC RETROFITTING OF HISTORICAL MASONRY HERITAGE STRUCTURES: A CASE STUDY OF AN ADOBE MASONRY BUILDING IN LIMA, PERU
}

\section{TIAGO MARTINS ${ }^{1 *}$, JULIA GARCÍA ${ }^{1}$, ALEJANDRO FERRÁNDEZ ${ }^{1}$, NICOLA TARQUE $^{2}$ AND JAIME FERNÁNDEZ ${ }^{1}$}

\author{
${ }^{1}$ Escuela Técnica Superior de Ingenieros de Caminos, Canales y Puertos \\ Universidad Politécnica de Madrid \\ Campus Ciudad Universitaria, 28040 Madrid, España \\ e-mail: tiago.martins@upm.es, web page: http://www.caminos.upm.es \\ ${ }^{2}$ Departamento de Ingeniería - Sección Ing. Civil, Pontificia Universidad Católica del Perú (PUCP) \\ Campus principal, Av. Universitaria 1801, San Miguel \\ Lima 32, Perú \\ e-mail: sntarque@pucp.edu.pe - web page: https://www.pucp.edu.pe/
}

Keywords: Adobe masonry, Seismic behaviour, Seismic retrofitting

\begin{abstract}
The need for seismic retrofitting on a historical masonry heritage structure raises questions that go beyond the improvement of its seismic behaviour after the intervention. Indeed, principles as minimum intervention or reversibility must be considered before a consensus decision can be reached, especially when this process is just a part of a broader and deeper intervention on this kind of building.
\end{abstract}

Moreover, the complexity to perform in-situ experimental tests results in the uncertainty on the masonry mechanical properties, which are typically assumed as a homogeneous and isotropic material. All these uncertainties, among others, result in the difficulty to predict the different possible failure mechanisms of the complete structure and its structural behaviour.

Through the analysis of different possible seismic strengthening solutions for a 19th century historical masonry heritage building these issues are tackled. The selected case study is the fort of Santa Catalina, an adobe masonry load-bearing wall building located in Lima, Peru, on which it has been decided to carry out its seismic retrofitting among the complete rehabilitation of the building. The Peruvian coast is classified as a high seismic activity zone, where an 8.0 $\mathrm{Mw}$ is expected to occur according to recent studies performed by the Geophysical Institute of Peru.

In this context, this work presents the results of a preliminary characterization of the selected adobe masonry building and the subsequent evaluation of its seismic vulnerability in order to define the fitting solution.

Thus, the ongoing research allows to define an effective seismic retrofit solution and respectful to the building's historic significance. 


\section{INTRODUCTION}

For centuries, the use of unreinforced masonry was common in Central and South America, Eastern Europe, the Himalayan region, Indian subcontinent and other parts of Asia [1]. Taking as an example the case of Peru, statistics show that adobe o rammed earth, still represent currently $30 \%$ of the predominant material of the houses' outer walls [2]. Many of those buildings, such as the mentioned case of Peru, were built on high seismic activity zones and, due to that, different seismic events have shown poor seismic performance of existing masonry structures [3]. It is noted that the Peruvian coast is classified as a high seismic activity zone, where an $8.0 \mathrm{Mw}$ is expected to occur according to recent studies performed by the Geophysical Institute of Peru $[4,5]$. In this context, seismic retrofitting of those masonry constructions is required for reducing their seismic vulnerability.

Different solutions, such as confinement, mesh reinforcement or junction strengthening, have been developed and implemented with the aim of improving seismic behaviour of masonry structures, and so reduce their future seismic vulnerability [1, 3, 6-9]. Nevertheless, in the case of historical masonry heritage buildings, in the decision process of their seismic retrofitting solution frequently intervene different factors, related with preservation principles or even with economical questions, that go beyond the strict improvement of the seismic behaviour of those buildings after the intervention. This may cause, in some cases, that the solution adopted is not the most effective from the point of view of seismic strengthening.
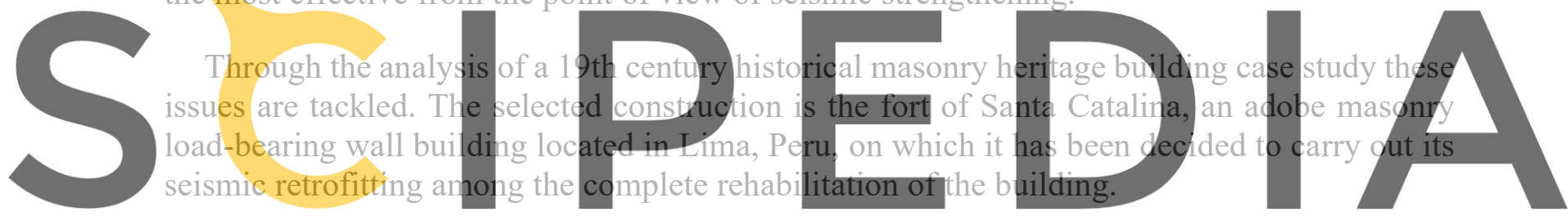

For this purpose, and taking into account that, in order to support correct pre-evaluation

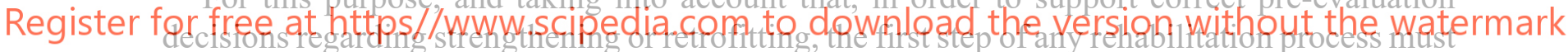

be the understanding of building's construction system and its so far performance [8], it was initially performed a building survey to characterize the structural and constructive solutions adopted, as well as a damage inspection of the building. The information obtained from the construction survey accomplished and the available literature on this topic, allowed the subsequent evaluation of its seismic vulnerability with the purpose of defining a suitable retrofitting solution. Hence, the paper presents the results of the analyses carried out and the seismic retrofit solution achieved for the case study building.

\section{CONSTRUCTION SURVEY}

In order to characterize structural and constructive solutions adopted on the case study building, as well as to collect data of building's seismic vulnerability, an extensive inspection campaign was carried out, whose results are described in this section. This allowed to complete the historical information of the building, create advanced 3D models and plans. In addition, a complete building damage inventory was also conducted with the purpose of evaluate the construction conservation condition and current damage grade. 
The analysis is narrowed to one of the buildings of the complex, called the "Cuadra". The structure was built in the XIX century by the Spanish during the colonial period. This unique building comprises all the features to be considered as highly valued and therefore make it worth of an intervention. Its past uses, reconstructions, the employed materials and building techniques make it a living witness of the history of Lima.

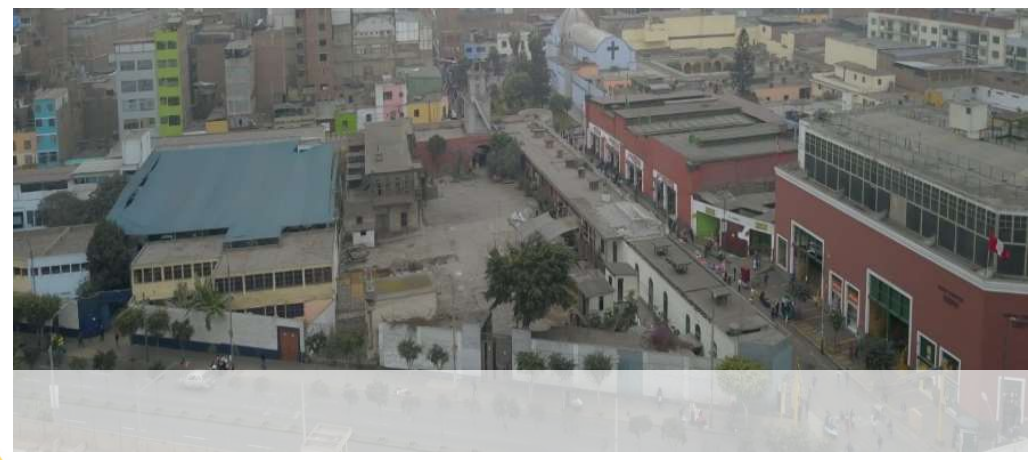

Figure 1. Aerial view of the fort of Santa Catalina.

\subsection{Structural behaviour}

The "Cuadra" is a two-story adobe masonry building. The first floor is made up of 5-meterhigh adobe walls while The benefit of the diff supports fewer shear stre are less. The second floor wood which is a flexible material that can supp wood which is a the
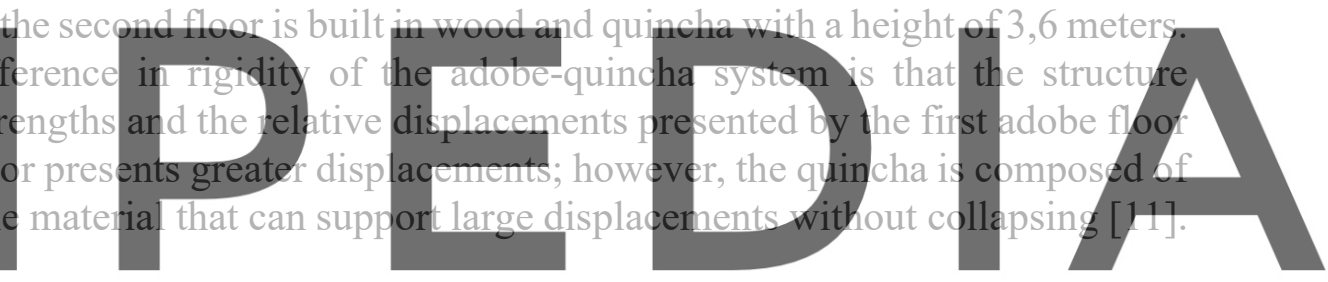

Register for free at https/fWWW/Scipedia.com to download the verston without the watermark

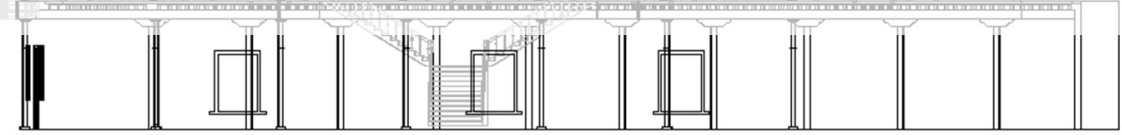

Figure 2. Front view of the building (Source: Escuela Taller de Lima, 2007).

The roofs lay on wooden girders sustained by quincha walls, a construction methodology consisting of wooden posts, wooden beams at the bottom and top and a combination of woven cane and clay as filler, which also partition the space into sixteen small rooms (Figure 3 ).

The loads from the second floor are transmitted to the masonry bearing walls and to a main wooden beam in the middle of the first story space, using wooden girders that lay directly on the central beam and are embedded in the adobe walls which constitute the enclosure of the first floor. On this level there are also two spaces separated from the main room by other adobe 
walls, as it can be seen in Figure 4.

The wooden beam is supported by various wooden pillars along its length, represented by the circles in the middle of the main space in Figure 4 . The two lateral alignments of circles represent the struts that were added afterwards to avoid collapsing.

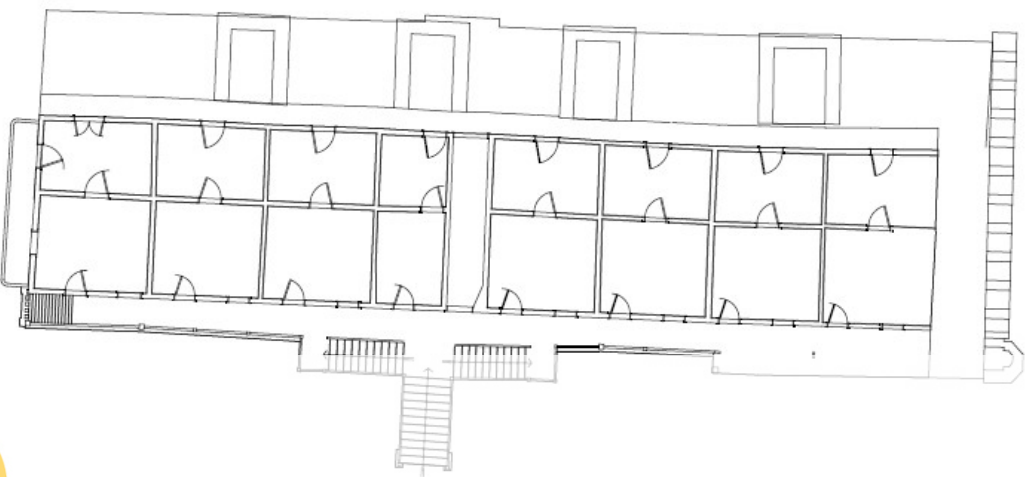

Figure 3. Second floor (Source: Escuela Taller de Lima, 2007).
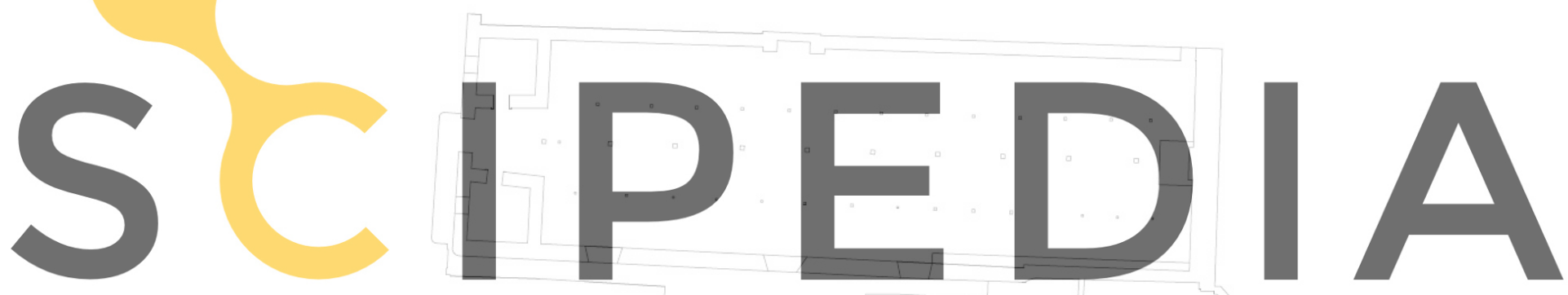

Register for free at https//www.scipedia.com to download the version without the watermark

Figure 4. First floor (Source: Escuela Taller de Lima, 2007).

The transmission of loads from the masonry walls to the ground is done through the foundation, built as was traditional in the period of construction of the fort. The walls are prolonged and embedded in the soil, with two layers: the upper one is made up of fifteen centimetres of brick with lime and sand mortar while the lower layer is made up of forty-five centimetres of round pebbles with soil mortar.

\subsection{Methodology}

The surveying campaign comprised a thorough identification of the materials involved in the structural behaviour of the building, as well as its aesthetics. However, the essential set of in situ tests required to characterize their mechanical properties could not be performed for the time being, nor the collection of samples to be tested in the lab. Since the fort is strongly 
protected by the Peruvian Government for being of high historical value, the permits could not be delivered for a research project like this.

Hence, a different approach was needed. The characterization of the materials was estimated employing the test results and properties from the same materials used in a nearby manor house project [19]. Since the house was built during the same period, in the same area and employing identical building techniques and materials, the resemblance allows to use the results for the ongoing research project.

\subsection{Damage survey}

The fort was last used as headquarters for the "Escuela Taller de Lima". Its administrators performed different projects for refurbishing and damage repair. However, the school closed, and the building changed hands, being now of the jurisdiction of the Ministry of Culture. After that, it was left almost abandoned. Thus, the level of damage in the building at the time of the survey was huge. These damages not only compromise the aesthetics of the structures but also affect their structural capacity, which is why it is necessary to carry out an in-situ data recompilation. The results are summarized in the following lines by means of photographs, as a previous step to define what type of reinforcement will be carried out in it.

Beginning with the first floor, the most notable damage to the facades are multiple fractures

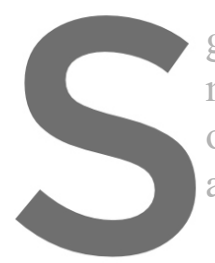
generally followed by masonry walls, with openings that serve as as well as at the corne
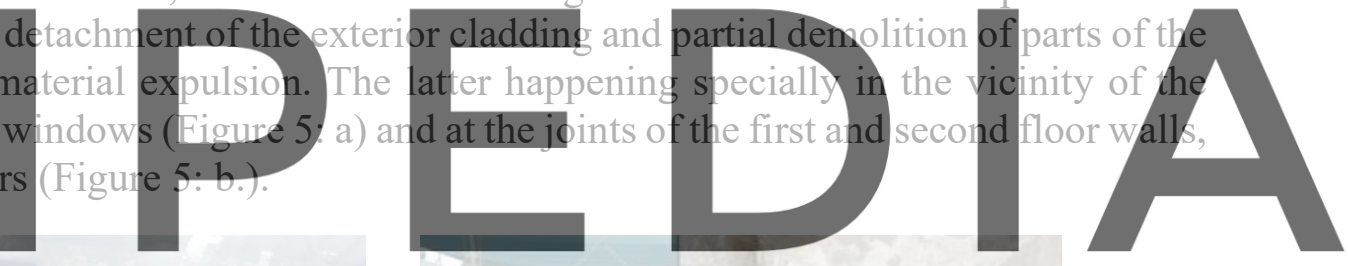

Register for free at https//www.scipedia.com to

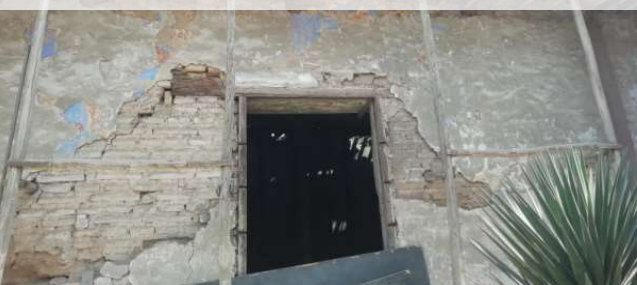

a. Cracks, cladding detachment and partial of walls

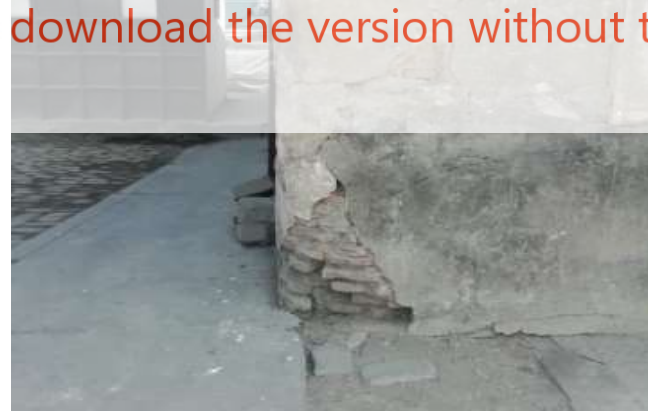

b. Partial demolition with material expulsion in corner

Figure 5. External facade of the first floor.

Inside this level, it also takes place detachments of material on the walls (Figure 6: a.). One of them, which served to separate a small room from the main one, has collapsed (Figure 6: b.). In addition, the presence of vertical cracks extends throughout all the load-bearing walls (Figure 6: c.), causing disconnection of all the edges between adobe masonry walls, making them work separately and not allowing a box effect (Figure 6: d.). Other important damages are those related 
to the beams, highlighting the multiple fractures in the main beam supporting the girders and the deterioration of the girders that separate both levels.

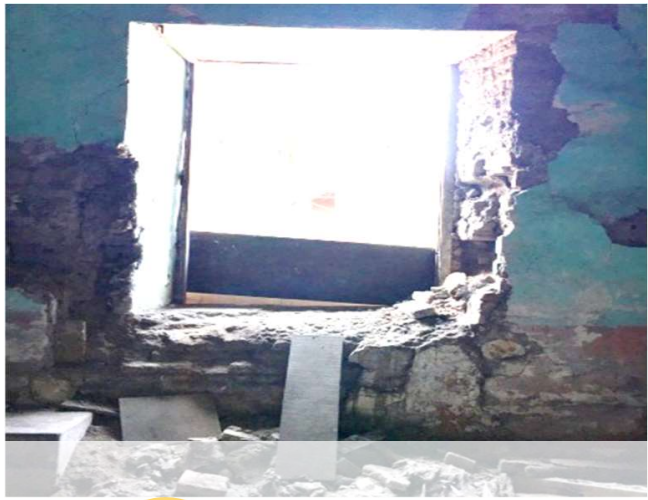

a. Partial demolition with material expulsion

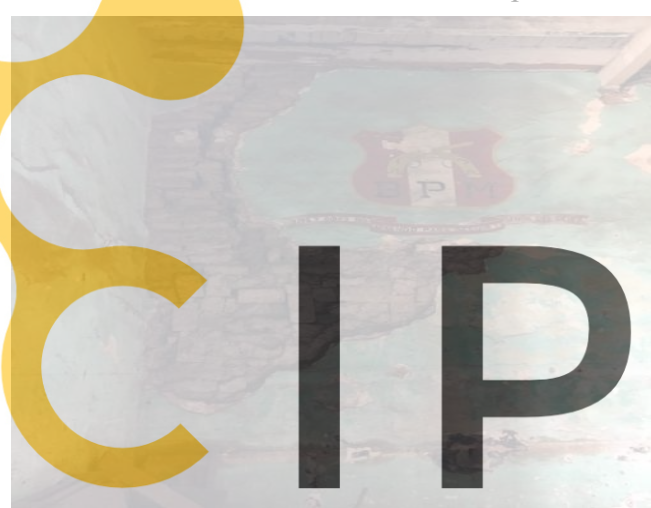

c. Vertical cracks

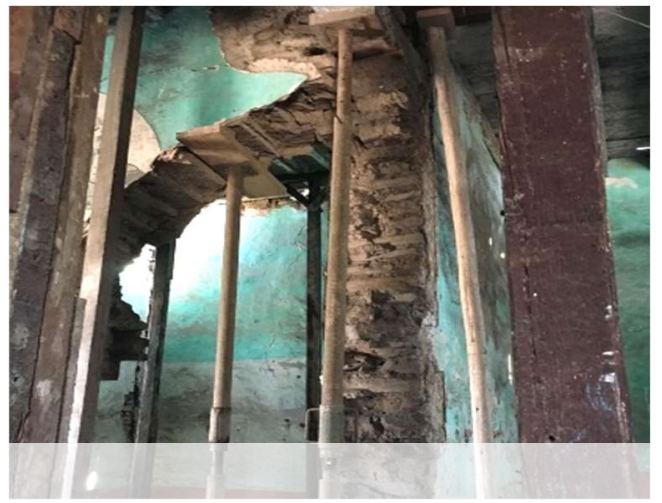

b. Collapsed wall sustained by props

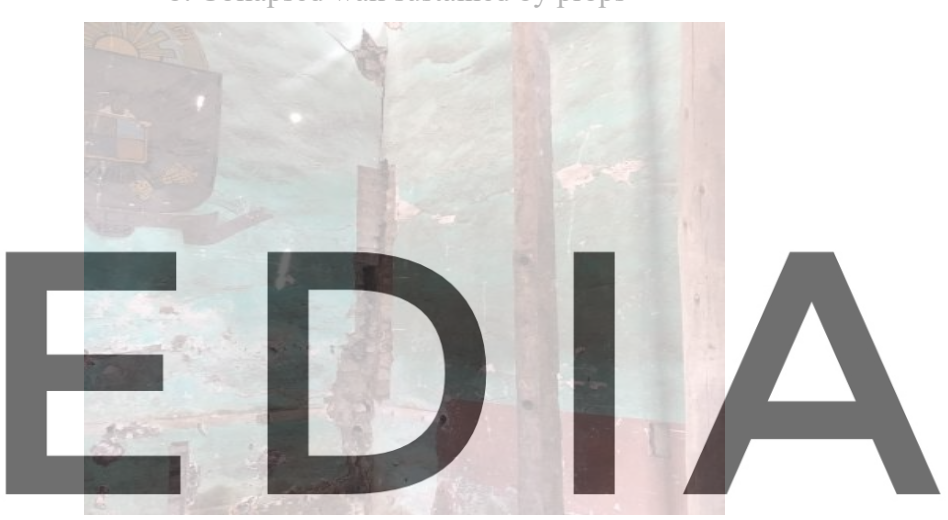

d. Disconnection of the edges

\section{Register for free at https//www.scipedia.com to download the version without the watermark}

Figure 6. First floor damages.

The analysis continues on the second floor. The only access to it is by a wooden stairway in a high state of deterioration. The quincha walls used as separation elements for the sixteen departments that conform the second floor have damages generated by the attack of xylophages. This causes the need to rebuild the quincha walls (Figure 7: a.) and the girders from the wooden slab as well because of their high deterioration. Finally, it can be seen how the walls of the rear facade, are inclined, making it necessary to support them with braces (Figure 7: b.).

In its current state the building can only stand thanks to a series of wooden and steel braces all around the main space, which support the main and secondary girders and avoid imminent collapse. Therefore, the retrofitting must begin with a reconstruction to provide the building its original mechanical properties. 


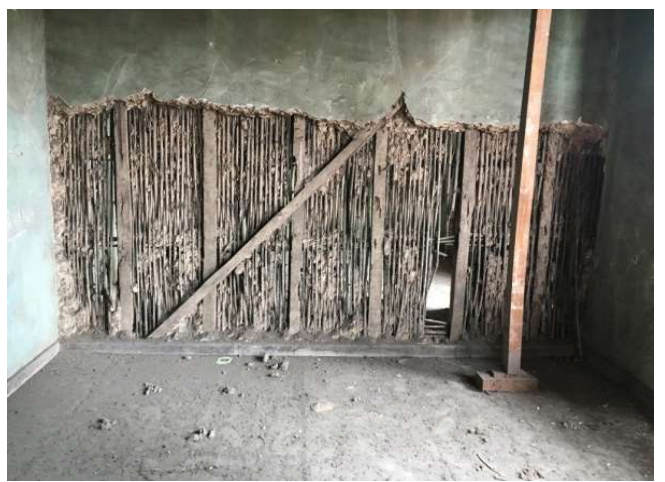

a. Damaged quincha walls

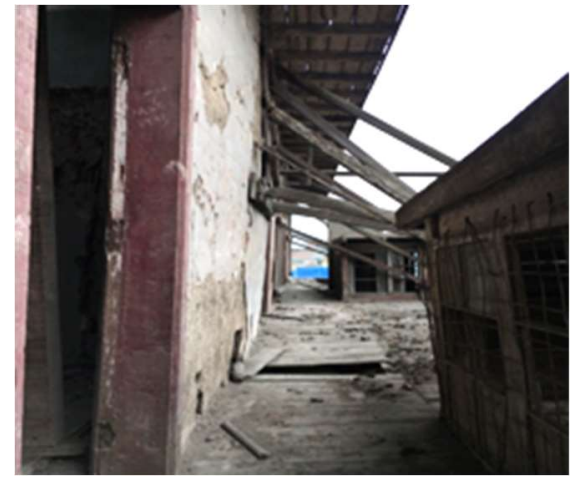

b. Inclined rear facade

Figure 7. Second floor damages.

\subsection{Seismic vulnerability assessment}

After an exposition of the mechanisms that govern the structural behaviour of the building, the materials' characteristics and the damages present in the structure, an assessment of its seismic performance must be done. For this purpose, the Peruvian Standard for seismic design of structures [12] is to be followed. In the case of earth structures, a special standard is employed [13].

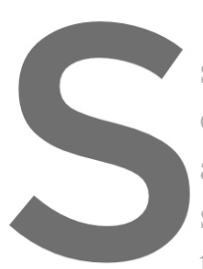

Lima is located in Zor seism is a ground accele of Fort of Santa Catalin

and a sandy matrix,

standard, for this area, spit the weight of the building.
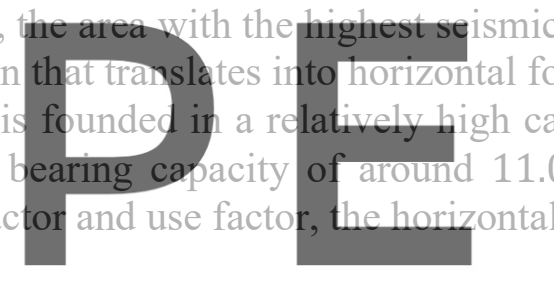

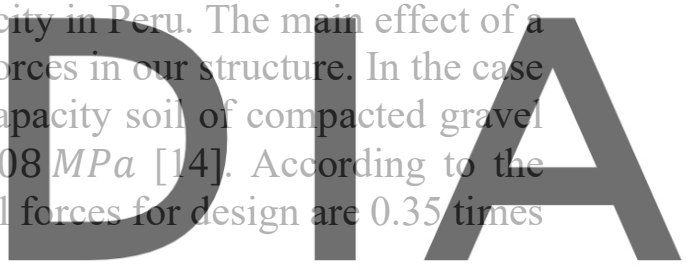

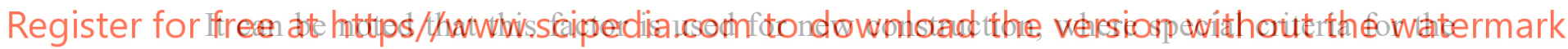
materials and the design are to be followed. However, for the reinforcement of the "Cuadra" there is no appliable standard or guidelines to follow, so a different approach oriented to literature and state of the art practices must be considered. What is more, the building has features that affect positively or negatively to its seismic performance and differ from today's design guidelines. Beginning with details from the original design, the ground plan configuration is inadequately asymmetrical and with a much longer dimension than the other. These long spans are not reinforced nor confined intermediately, causing out-of-the-plane stresses induced by the earthquake to be inacceptable. What is more, the vertical loads from the second floor are not transmitted straight to the adobe bearing walls but with a certain gap, inducing moments in the walls. Lastly, the enormous damages existing in the structure barely allow it to resist its own weight, much less the effects of an earthquake, with all the adobe walls working separately due to the disconnected corners.

On the other hand, the combination of a stiff first floor with a flexible quincha second floor, as mentioned in chapter 2.1, presents a good seismic performance. This combination of building materials was settled by the Spanish through a Royal Order, after the huge earthquake in 1756 [18]. This combination, together with the good quality of the soil and the foundation, is probably 
the reason why the building remains standing and has not already collapsed in previous earthquakes.

Finally, it must be noted that the most likely outcome (without an intervention) in the event of a seism is the collapse of the building. However, a complete seismic vulnerability assessment is still needed, for which material testing will become vital. The retrofitting alternatives, consequently, must be designed to avoid the main failure modes under cyclic loads for this particular building.

\section{ANALYSIS OF RETROFITTING ALTERNATIVES}

Given the seismic vulnerability of the building achieved from the construction survey data assessment carried out, a range of possible retrofitting alternatives were evaluated in order to improve the seismic behaviour of this construction. Based on the information obtained from the field work research and the available reference literature on this topic, the retrofitting solutions were analysed according to different criteria, such as seismic response, conservation principles, material and installation costs, installation feasibility and compatibility. Table 1 presents an evaluation of the common retrofitting solutions. In this line, some of them are immediately discarded for being too invasive and incompatible with the original building materials.

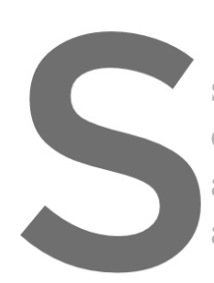

According to the a structure presents cuit actions and weather assumed by its walls,
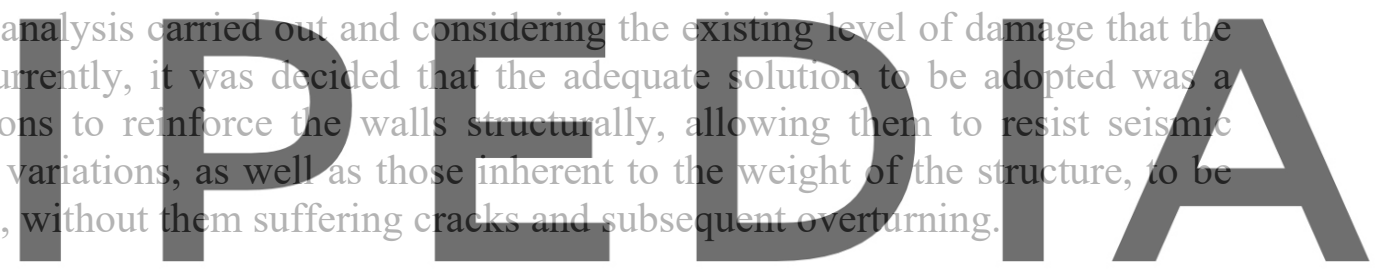

Table 1. Summary of the evaluation of the most common retrofitting solutions

Register for free at https//www.scipedia.com to download the version without the watermark

The confinement prevents disintegration and improves ductility and energy dissipation of

unreinforced masonty buildings büt has limited effect on the uitimate load resistance [16]. Seismic Actually, the masonry being confined by reinforced concrete frame may behave effectively as response a diagonal compressive strut under lateral loading and may improve the behaviour considerably as compared to what is observed in case of a bare frame (frame containing concrete columns and beams only) [1].

Conservation It is an invasive and destructive procedure, much more intrusive than permitted by values criteria conservation standards [6].

Costs and This type of seismic retrofit is expensive [6]. Indeed, requires demolition and reconstruction feasibility of wall sections making it uneconomical [1].

Compatibility The combination of concrete and adobe may result in problems of material compatibility that will be realized only years after the original retrofit [6]

Horizontal superior confinement with concrete bond beams placed at the tops of walls below the roof Provides out-of-plane strength and stiffness. Also, lateral support and continuity enough to

Seismic transmit the loading from the out-of-plane walls to the in-plane walls. However, bond beam

response when used without other retrofit measures is not enough to restrain the movements of the cracked block sections of the walls [6]

Conservation It's an invasive and destructive procedure [6] much more intrusive than permitted by values criteria conservation standards [6]. 


\begin{tabular}{cl}
\hline $\begin{array}{c}\text { Costs and } \\
\text { feasibility }\end{array}$ & This type of seismic retrofit is expensive and requires the removal of the roof system [6]. \\
\hline Compatibility & $\begin{array}{l}\text { The combination of reinforced concrete and adobe may result in problems of material } \\
\text { compatibility that will be realized only years after the original retrofit [6]. }\end{array}$ \\
\hline $\begin{array}{c}\text { External polymer mesh (industrial geogrid and construction site "soft" fence) } \\
\text { Seismic } \\
\text { response }\end{array}$ & $\begin{array}{l}\text { Increases the stiffness, strength and deformation capacity of the adobe walls [15]. Prevents } \\
\text { partial or total collapse of adobe buildings [7]. Placing the mesh in critical locations can be } \\
\text { enough to avoid collapse [7]. The mud plaster over the external reinforcement increases the } \\
\text { initial shear strength and the stiffness of the walls [7]. }\end{array}$ \\
\hline $\begin{array}{c}\text { Conservation } \\
\text { values criteria }\end{array}$ & $\begin{array}{l}\text { It is not reversible and cannot be applied on surfaces that must be preserved in their original } \\
\text { form (wall paintings, frescoes, adornments, etc.) [17]. }\end{array}$ \\
\hline $\begin{array}{c}\text { Costs and } \\
\text { feasibility }\end{array}$ & $\begin{array}{l}\text { Should be placed on both sides of the walls, and tightly connected through the walls [7]. It is } \\
\text { convenient to cover the reinforcement mesh with mud plaster, but it is not necessary to } \\
\text { completely cover the walls with the polymer mesh [7]. It's an economical solution [7]. }\end{array}$ \\
\hline Compatibility & The mesh works well together with the adobe walls even for high levels of seismic intensity [7]. \\
\hline
\end{tabular}

\subsection{Wooden porticos}

Although reinforced concrete would be a more efficient solution by cost and seismic response, according to Table 1 the high incompatibility of concrete with the original materials makes its use unadvisable.

This solution consists in the insertion of wooden profiles in the walls that make up the building's facades. They shall be arranged at the corners and along the length of the same,
embedded in its section. They shall be linked by another wooden beam, arranged horizontaly,
at the intersection between the two levels in the form of porticos that receive the loads from the
upper floor and distribute then to the ground.

3.2. Repair of the adobe walls

Register for free at https//www.scipedia.com to download the version without the watermark Adobe walls will be reconstructed (for those which already collapsed) or repaired. The damaged sections of the walls will be torn down and rebuilt employing similar adobe bricks to the original ones.

\subsection{Geogrid retrofit}

In order to prevent partial or total collapse of building's adobe walls as well as to increase their stiffness, strength and deformation capacity, a state-of-the-art polymer mesh of industrial geogrid is going to be applied for the seismic retrofit of the building. This intervention will be completed with a cover of the reinforcement mesh made of mud plaster.

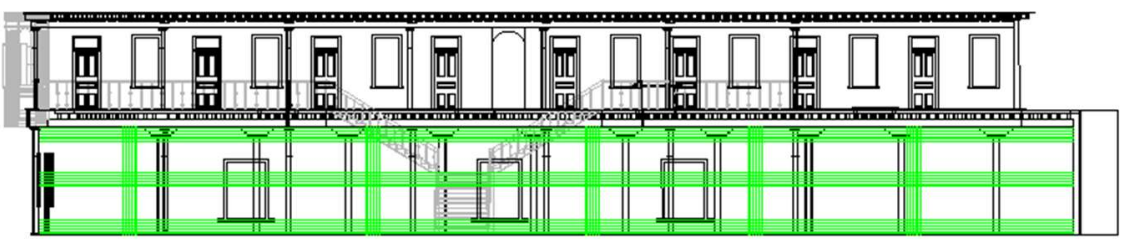

Figure 8. Frontal view of the building with the geogrid applied. 


\subsection{Lime and earth mortar}

Once again, the more efficient solution of application of shotcrete cannot be performed due to the high incompatibility and lack of "breathing" for the adobe wall. In this line, plaster will be made with a mortar composed of lime and earth, both natural materials, constituting a much less invasive solution.

\subsection{Replacement of the central beam, pillars and slab girders}

The damaged wood beam shall be removed, and the wooden girders repaired or replaced in order to allow a central open space without the multiple struts currently present in the structure.

The already mentioned inclusion of porticos will reduce the number of pillars needed for the central beam, giving the interior more usefulness.

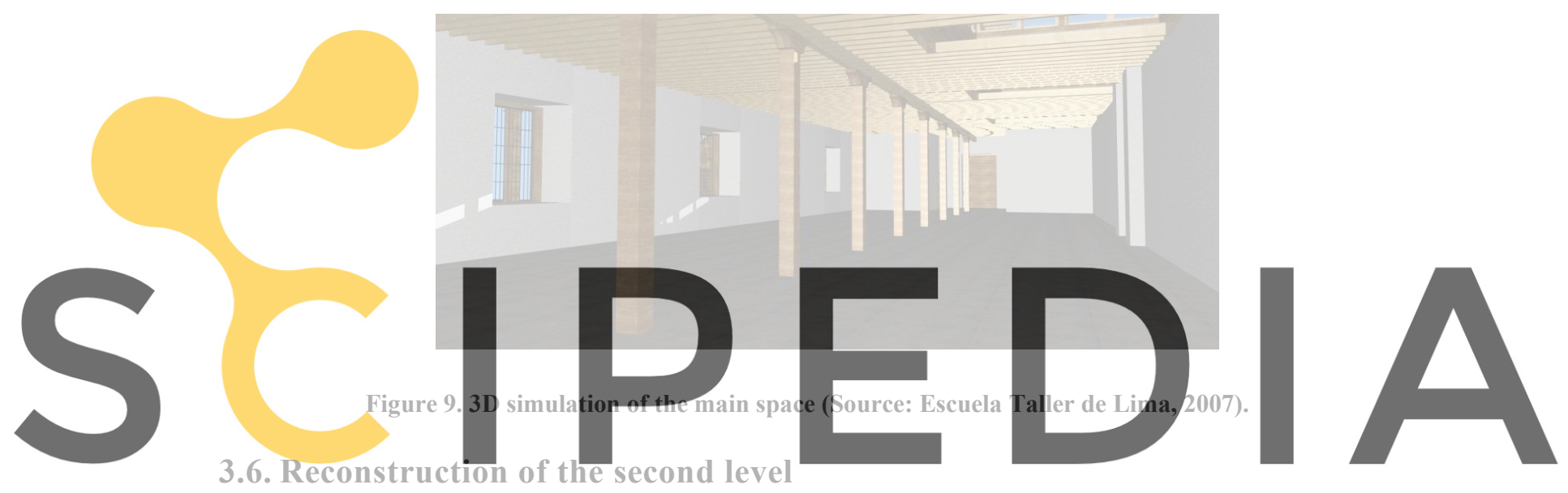

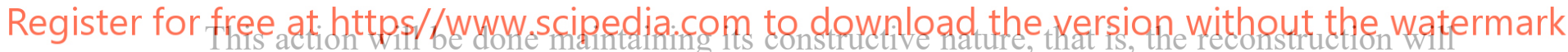
be in quincha panels between wooden columns that constitute the different divisions in the original plans. In addition, the wooden slab, on which the upper level rests, will be rebuilt consisting of wooden beams that will distribute the loads they receive towards the bearing walls of the lower level.

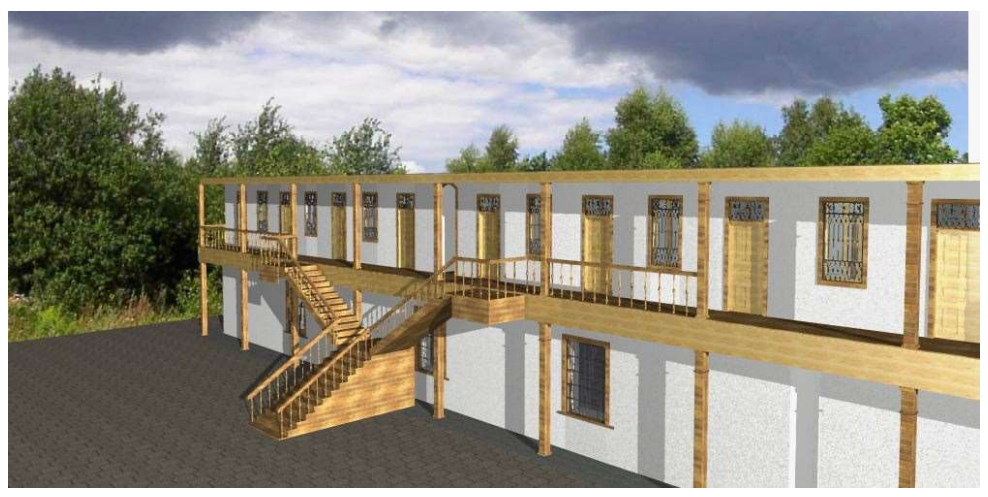

Figure 10. 3D simulation of the main facade (Source: Escuela Taller de Lima, 2007). 


\section{CONCLUSIONS}

The results achieved in the analysis of the case study building permitted to accomplish relevant information about the possible structural and constructive solutions to be adopted, along with its current damage level.

This knowledge allowed the preliminary evaluation of its seismic vulnerability and a proposal of an appropriate retrofitting solution for the building.

A future research based on materials characterization and a numerical modelling structural assessment of building's seismic performance, with and without the retrofitting measures, should be conducted in order to confirm the obtained results on the seismic vulnerability of the construction and the suitability of the retrofitting solutions proposed.

One conclusion is clear: the high value of the building and the excellent retrofitting results that can derive from the intervention make it worth it to be restored.

This paper contributes also to the knowledge of this kind of adobe masonry historical heritage buildings, especially the Peruvian ones, as well as to a possible approach to its assessment, and the information obtained can be used as a reference for future case studies.

\section{ACKNOWLEDGMENTS}

The authors are greatly acknowledged for the contribution of Leslie Quiroz, Luiggi Vargas, Edwards Gonzales, Jaffet Villena and the personnel of the Laboratory of Structures of Pontificia Universidad Católica del Perú in this project.

A special recognition for the architect Jorge Larrea for his contributions and support for the realization of this work; and to Escuela Taller de Lima for the access to their files and previous works about the fort of Santa Catalina.

\section{REFERENCES}

[1] Bhattacharya, S., Nayak, S. and Chandra, S. A critical review of retrofitting methods for unreinforced masonry structures, Int. J. Disast. Risk Reduct., 7 (2014), pp. 51-67.

[2] Instituto Nacional de Estadística e Informática (INEI) - PERÚ, Características de las viviendas particulares y los hogares. Censos Nacionales de Población y Vivienda (2017).

[3] Tarque, N., Salsavilca, J., Yacila, J. and Camata, G. Multi-criteria analysis of five reinforcement options for Peruvian confined masonry walls. Earthquake Struct 17(2) (2019), pp. 205-219.

[4] Tavera, H. Escenario de Sismo y Tsunami en el borde occidental de la región central del Perú, Dirección de Sismología, Instituto Geofisico del Perú, Lima- Perú. 30 pp. (2014).

[5] Tavera, H. Actualización del escenario por sismo, tsunami y exposición en la región central del Perú, Dirección de Sismología, Instituto Geofísico del Perú, Lima- Perú. 24 pp. (2017).

[6] Tolles, L., Kimbro, E., Webster, F. and Ginell, W. Seismic Stabilization of Historic Adobe 
Structures, Final Report of the Getty Seismic Adobe Project, The Getty Conservation Institute, Los Angeles (2000).

[7] Blondet, M., Torrealva, D., Vargas, J., Velasquez, J. and Tarque, N. Seismic reinforcement of adobe houses using external polymer mesh. First European Conference on Earthquake Engineering and Seismology, Geneva, Switzerland (2006).

[8] Rouhi, J., and Hejazirad, F. A Review on the Large-Scale Modeling for Seismic Strengthening of Adobe-Mud Brick Structures, International Conference on Civil Engineering, Architecture and Urban Management in Iran, Tehran University (2018).

[9] Yacila, J., Salsavilca, J., Tarque, N. and Camata, G. Experimental assessment of confined masonry walls retrofitted with SRG under lateral cyclic loads, Engineering Structures, 199 (2019) 109555.

[10]Tavares A., D’Ayala D., Costa A. and Varum H. Construction Systems. In: Costa A., Guedes J., Varum H. (eds) Structural Rehabilitation of Old Buildings. Building Pathology and Rehabilitation, vol 2. Springer, Berlin, Heidelberg (2014).

[11]Santa María, A.E. and Torrealva, D.E. Comportamiento dinámico de una estructura mixta de dos pisos compuesta por adobe y quincha, Pontificia Universidad Católica del Perú: Facultad de ciencias e ingeniería. Lima, Perú (2018).

[12]MVCS. Norma Técnica E.030 Diseño Sismorresistente. Ministerio de Vivienda, Construcción y Saneamiento. Perú (2018).

[13]MVCS. Norma E.080 Diseño y Construcción con Tierra Reforzada. Ministerio de Vivienda, Construcción y Saneamiento. Perú (2017).

[14]Tavera, H., Bernal, I. and Gómez, J.C. Zonificación sísmico-geotécnica para el centro histórico de Lima, Sistema de Información para la Gestión del Riesgo de Desastre, Centro Nacional de Estimación, Prevención y Reducción del Riesgo de Desastres (2010).

[15]Blondet, M., Villa Garcia, G., Brzev S. and Rubiños, A. Earthquake-resistant construction of adobe buildings: A tutorial. Oakland: 2010 Earthquake Engineering Research Institute (2011).

[16]Elgawady, M., Lestuzzi, P., and Badoux, M. A Review of Conventional Seismic Retrofitting Techniques for URM. 13th international brick and block masonry conference. Amsterdam, Netherlands (2004).

[17]Peña, F. and Lourenço, P. Criterios para el refuerzo antisísmico de estructuras históricas. Revista de Ingeniería Sísmica. 87 (2012) pp. 47-66 Sociedad Mexicana de Ingeniería Sísmica Distrito Federal, México (2012).

[18]Blondet, M., Vargas, J., Tarque, N. and Iwaki, C. Seismic resistant earthen Construction: the contemporary experience at the Pontificia Universidad Católica del Perú. Informes de la Construcción Vol. 63, 523, 41-50. Julio-septiembre 2011.

[19]Cancino, C., Lardinois, S., D’Ayala, D., Fonseca, C., Torrealva, D., Vicente, E. and Villacorta, L. Proyecto de Estabilización Sismorresistente: Estudio de edificaciones tipológicas, Vol. 1. The Getty Conservation Institute. Los Angeles (2012). 